\title{
Decadal-scale persistence of predation potential in coral reef communities
}

\author{
Richard B. Aronson* \\ Dauphin Island Sea Lab, 101 Bienville Boulevard, Dauphin Island, Alabama 36528, USA \\ and \\ Department of Marine Sciences, University of South Alabama, Mobile, Alabama 36688, USA
}

\begin{abstract}
Interpretations of ecological relationships are often influenced by the scale of observation. Scale independence is a useful null hypothesis against which to test scale-dependent alternative hypotheses. This study examined the interaction between predatory fishes and the ophiuroids on which they prey in back-reef habitats in the Caribbean. Predation potential was measured as the mortality of tethered ophiuroids at shallow, rubble-dominated sites in Jamaica and St. Croix on 2 temporal scales: seasonally over 3 уг and annually over a decade. Diel variations within sites and differences between sites were similar between scales. Hurricanes had no effect on predation potential on either scale. Predation potential at a third back-reef site, in Belize, was consistently different from the sites in Jamaica and St. Croix on the annual scale. The results suggest that some ecological relationships are stable at multiple temporal scales. For cases in which scale independence can be demonstrated over a particular range of scales, it should be possible to make long-term predictions on the basis of short-term observations.
\end{abstract}

KEY WORDS: Predation - Scale $\cdot$ Stability $\cdot$ Ophiuroidea $\cdot$ Coral reefs

\section{INTRODUCTION}

A substantial body of recent literature asserts that scale is of paramount importance in interpreting biological systems (Allen \& Starr 1982, Dayton \& Tegner 1984, Gould 1985, White \& Pickett 1985, O'Neill et al. 1986, Chesson \& Huntley 1989, Wiens 1989, Menge \& Olson 1990, Levin 1992, Wu \& Loucks 1995, Thrush et al. 1997, and many others). Perhaps the most salutary effect of our recognition of the 'problems of scale' is the coalescence of ecology and paleobiology into a single, coherent life science (Gould 1981, Miller 1990). At this point, many neontologists routinely assume that observations at different scales will produce differing perceptions of pattern and process. That is not always the case, however, and a number of authors have offered scale-independent interpretations of ecological and evolutionary phenomena (Vermeij 1978, 1987, Levinton 1988, Hoffman 1989, Aronson 1994, Aronson \& Plotnick in press). Nevertheless, many studies suggest-

·E-mail: raronson@jaguar1.usouthal.edu ing scale independence probably go unpublished, because they are perceived as negative or non-significant results (Connell 1983, Peters 1991, Csada et al. 1996). These concerns are compelling ecologists to consider population and community dynamics on multiple scales of space and time, including those large scales at which measurements are extremely difficult (e.g. Dayton et al. 1992, Doherty \& Fowler 1994, Schneider 1994, Brown 1995, Menge 1995, Underwood \& Chapman 1996, Levin et al. 1997). Regardless of where one stands on the scale issue, scale independence remains a useful null hypothesis against which to test scale-dependent alternatives

Similarity between the ecological and evolutionary effects of skeleton-crushing predation is a prime example of scale independence. Increased expression of defensive traits in the architecture of gastropod shells has been tied to increased predation by fish and crustaceans on local, regional, and global spatial scales, as well as on ecological, evolutionary, and macroevolutionary temporal scales (Kitching \& Lockwood 1974, Vermeij 1977, 1978, 1987, Hughes \& Elner 1979, 
Wellington \& Kuris 1983, Seeley 1986, Appleton \& Palmer 1988, West et al. 1991). In an analogous fashion, predators limit the distribution of dense populations of epifaunal, suspension-feeding ophiuroids and other echinoderms on multiple spatio-temporal scales (Meyer \& Macurda 1977, Holme 1984, Meyer 1985, Oji 1985, Aronson \& Sues 1987, Aronson 1989a, b, 1992a, Aronson et al. 1997).

Ophiuroids are numerically important constituents of the cryptofaunas of coral reefs (Kissling \& Taylor 1977, Sloan et al. 1979, Lewis \& Bray 1983, Sides \& Woodley 1985, Hendler \& Littman 1986, Moran \& Reaka-Kudla 1991, Aronson 1993). Their cryptic lifestyle reflects high levels of predation by fishes on invertebrates in general (Vermeij 1978, Meyer 1985) and ophiuroids in particular (Sides \& Woodley 1985, Aronson 1987, 1992b, Sides 1987) in reef communities. Although ophiuroids occur commonly in crevices and under rubble on coral reefs, they are ordcrs of magnitude less abundant on reefs than in refuge habitats where predatory reef fishes are absent (Aronson \& Harms 1985).

This paper explores the ecology of predation on ophiuroids living under coral rubble at 2 widely separated back-reef sites in the Caribbean on 2 temporal scales: seasonally over a 3 yr period and annually over a decade. I test the following null hypotheses: (1) the potential for predation on ophiuroids exhibits similar patterns of within-site variation and between-site difference on both temporal scales, and (2) the potential for predation on ophiuroids exhibits similar day-night differences on both temporal scales. In other words, the prediction is that predation potential exhibits persistence and/or resistance stability (Pimm 1991) across the 2 time scales.

\section{STUDY AREAS}

This study was conducted primarily in the back-reef habitats of 2 windward-facing Caribbean reefs: DisCovery Bay, Jamaica, and Rod Bay, St. Croix, United States Virgin Islands. A third site, Carrie Bow Cay, Belize, was examined on the annual scale only and was compared qualitatively to the 2 primary sites. Aronson (1987, 1992b) summarized previous descriptions of these sites, which are briefly abstracted here. Water temperature was similar at the 3 sites during the course of the study (Aronson 1992b, unpubl. data).

The Jamaican site was the West Back Reef of Discovery Bay, near the Discovery Bay Marine Laboratory on the north coast of the island $\left(18^{\circ} 30^{\prime} \mathrm{N}, 77^{\circ} 20^{\prime} \mathrm{W}\right)$. Hurricane-generated coral rubble occurs in patches of $-200 \mathrm{~m}^{2}$ at 1 to $2 \mathrm{~m}$ depth within a large bed of turtlegrass Thalassia testudinum. Discovery Bay is heavily fished, to the extent that even wrasses and other small reef fishes are exploited for human consumption.

Rod Bay is a back-reef area on the southeastern coast of St. Croix $\left(17^{\circ} 44^{\prime} \mathrm{N}, 64^{\circ} 35^{\prime} \mathrm{W}\right)$. Volcaniclastic debris of Cretaceous age and Holocene-to-Recent, hurricane-generated coral rubble are scattered over a sandy substratum at $1 \mathrm{~m}$ depth. There is some fishing activity in Rod Bay, although considerably less than in Discovery Bay (Aronson 1992b).

The site in Belize was the coral rubble zone behind the reef crest at Carrie Bow Cay, on the Belizean Barrier Reef $\left(16^{\circ} 48^{\prime} \mathrm{N}, 88^{\circ} 05^{\prime} \mathrm{W}\right)$. This habitat is characterized by hurricane-generated, imbricated plates of rubble of the elkhorn coral Acropora palmata in $\leq 1 \mathrm{~m}$ depth. Fishing activity is very limited at this site.

The study sites will henceforth be referred to as Jamaica, St. Croix, and Belize. These general locality names will be used instead of the specific site names as a convenience to the reader Their use should not be taken to imply that results from a site can be generalized to a larger area encompassing that site.

\section{METHODS}

Predation potential is defined as the propensity of predators in a habitat to consume individuals of the focal prey species (Aronson 1987, 1989a). It integrates the abundance, species composition, and feeding preferences of predators, as well as the availability of alternative prey species in that habitat. Predation potential was measured on both temporal scales by means of tethering experiments.

Individuals of one back reef ophiuroid species, Ophiothrix orstedii $(=0$. oerstedi), 6 to $11 \mathrm{~mm}$ in disk diameter, were collected by hand and brought into the laboratory. They were tethered by passing a threaded needle through the mouth and out the aboral disk. The cotton-wrapped polyester carpet thread, which was 2 to $3 \mathrm{~cm}$ long, was tied to a lead fishing weight. Each ophiuroid-weight assembly was clipped to a loop of wire, which was in turn attached to a larger lead weight that had been placed in the rubble habitat at the site at least $24 \mathrm{~h}$ in advance. A small buoy on a $1 \mathrm{~m}$ line marked each larger weight. Between 13 and 16 tethered $O$. orstedii were deployed, 2 to $3 \mathrm{~m}$ apart, at each field site during one $4 \mathrm{~h}$ daytime period (08:30 to 12:30 h Local Standard Time) and one $8 \mathrm{~h}$ nighttime period (20:30 to 04:30 h LST) per site-visit.

The short length of the thread ensured that the tethered ophiuroids were restrained from crawling into refuges and that they were exposed continuously to predators. After the deployment period, the fishing weights were retrieved and the mortality of tethered Ophiothrix orstedii was assessed as the proportion of 
individuals that had disappeared from the tethers. An extensive series of laboratory controls and field observations indicated that the ophiuroids were unable to escape the tethers, that they survived the treatment with minimal damage, that piercing the disk did not increase their attractiveness to predatory fishes, and that the ophiuroids remained quiescent on the open substratum during the experiments (Aronson \& Harms 1985, Aronson 1988, 1992b).

Ophiothrix orstedii is one of the least palatable ophiuroids in the back reef, due at least in part to its long, sharp, hyaline (glassy) calcite arm spines (Aronson 1988). Using this species rather than a species more palatable to predators increased the probability of detecting differences in predation potential by decreasing the likelihood of saturating $(100 \%)$ mortality in the tethering experiments (Aronson 1992b). Even so, mortality rates in some of the daytime experiments at the 2 primary sites would have reached saturation had the experiments run for $8 \mathrm{~h}$ instead of being limited to $4 \mathrm{~h}$. Saturating mortality often occurred in the $4 \mathrm{~h}$ daytime experiments in Belize.

Peterson \& Black (1994) have objected to tethering experiments because they may lead to 2 types of errors. First, tethered prey not only cannot escape, but they represent novel stimuli to predators. This was the rationale for using tethering techniques to measure predation potential rather than predation pressure (Aronson 1987, 1989a, Aronson \& Heck 1995). The second difficulty with tethering experiments hinges on the possibility that different types of predators in different treatments respond differently to the tethered prey. When this occurs, tethering experiments cannot even be used for among-treatment comparisons of predation potential, because the results are confounded by a lack of control (i.e. there is an interaction between tethering and treatment; Peterson \& Black 1994). In the present study, the same novel stimulus was presented in the same habitat to the same suite of predatory fish species, although the abundances of those species varied among sites and site-visits (Aronson 1992b, unpubl. data). The design of these tethering experiments provided a reasonable, relative measure of predation potential for comparison across scales.

Tethering data were collected seasonally in Jamaica and St. Croix from the winter of 1989 through the fall of 1991, although it was not possible to visit both sites in each season of each year. For the annual-scale portion of the study, tethering experiments were conducted each year for $10 \mathrm{yr}$ in Jamaica and in 7 different years in St. Croix during the period 1987-1996. For each site in each year of the period 1989-1991, the site-visit used in the annual-scale analysis was the first site-visit of the year to include other ecological observations, collected for a related study. Using other site-visits from 1989-1991 in the annual-scale analysis did not affect the results.

Statistical hypotheses concerning the sources of variation in predation potential were tested by analysis of variance (ANOVA). Randomized incomplete-block designs were used, in which seasons or years were the blocks and site and time of day were fixed factors (see Sokal \& Rohlf 1981). The tethering data were expressed as proportional mortalities, and the $8 \mathrm{~h}$ nighttime data were divided by 2 to make them comparable to the $4 \mathrm{~h}$ daytime data in the ANOVAs. A dearth of site-visits in the spring months prevented the spring tethering data from being included in the seasonalscale analyses. However, the spring data were used in graphical comparisons.

$F_{\max }$ and Lilliefors tests demonstrated that the tethering results from Jamaica and St. Croix, pooled by site and, in a separate analysis, by time of day, did not conform to the homogeneity of variances or normality assumptions of ANOVA. The proportional mortality data were, therefore, arcsine-transformed. Transformation removed heterogeneity of variances and departures from normality ( $p>0.05$ in all $F_{\text {max }}$ and Lilliefors tests, respectively, after arcsine transformation).

Two randomized block ANOVAs were performed in the seasonal-scale analysis. The first ANOVA considered the 3 years $(1989,1990$ and 1991) as blocks. The fixed factors were site ( 2 site treatments: Jamaica and St. Croix), season ( 3 season treatments: winter, summer, and fall) and time of day (2 time-of-day treatments: daytime and nighttime). This analysis detected no effect of season (see 'Results'). Therefore, a second randomized block ANOVA was run, in which the 9 seasonal divisions from the 3 yr were the blocks and the fixed factors were site and time of day. The second seasonal-scale ANOVA was compared to an ANOVA on the annual-scale tethering data. In the annual-scale analysis the blocks were the 10 years (1987-1996), and the fixed factors were again site (2 treatments) and time of day (2 treatments).

All randomized block ANOVAs were performed under the assumption of no block $\times$ factor interactions. In other words, the ANOVAs tested null hypotheses of no treatment effects in any block. The F-tests therefore corresponded to 'Model 2' of Newman et al. (1997).

The tethering data for Belize, collected annually over the period 1986-1995, violated both assumptions of parametric statistics. All the tethered ophiuroids were eaten during most of the daytime experiments, resulting in non-normal data that exhibited extremely low variability (Lilliefors and $F_{\max }$ tests, $\mathrm{p}<0.05$, even after transformation). These data, therefore, could not be compared by ANOVA to the annual-scale data from Jamaica and St. Croix. A graphical analysis of the tethering data from all 3 sites showed statistical comparison to be unnecessary (see 'Results'). 

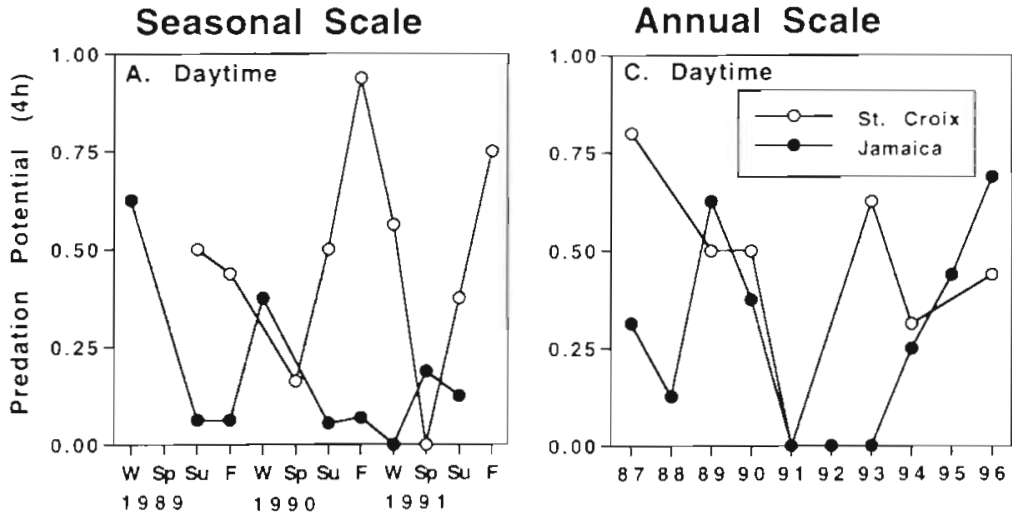

effect of season when the 3 years were considered as blocks. Predation potential was significantly greater in St. Croix than in Jamaica and significantly greater during the day than at night (Table 1, Fig. 2A). None of the interaction terms was significant. Block effects were tested under the assumption of no block $\times$ factor interactions (Sokal \& Rohlf 1981, Zar 1984, Newman et al. 1997). If this assumption was valid, then there was no significant block (= year) effect

The lack of a seasonal effect made it
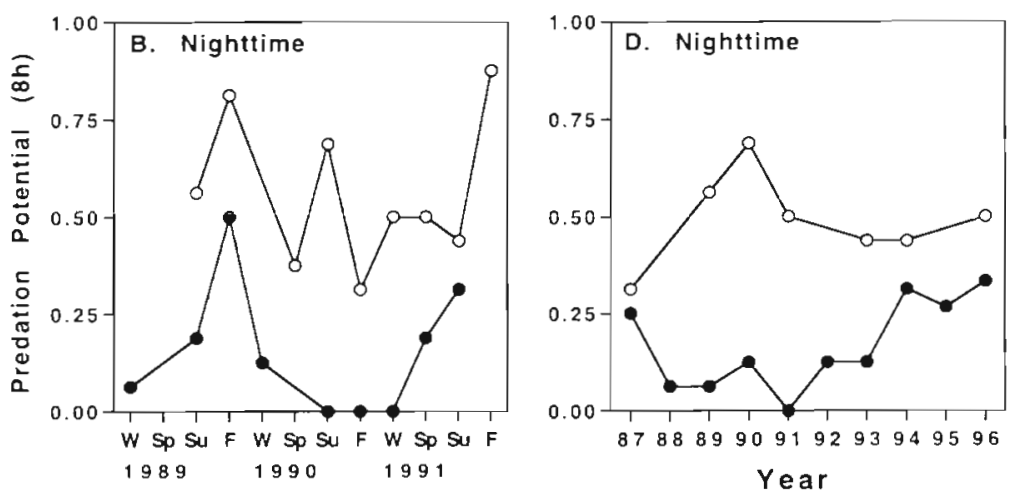

Fig. 1. Time series of predation potential at the 2 sites, measured as the mortality of tethered Ophiothrix orstedii, on both scales. Seasonal-and annualscale data: (A) and (C) $4 \mathrm{~h}$ daytime experiments; (B) and (D) $8 \mathrm{~h}$ nighttume experiments. Results of the nighttime experiments are divided by 2 in the ANOVAs but not in the figures possible to consider the seasons of the 3 years as blocks. A randomized block ANOVA, in which the 9 seasonal divisions were blocks, again showed significant effects of site and time of day (Table 2). As before, there was no significant site $x$ time interaction. There was also no significant effect of block, again assuming no block interactions.

The ANOVA design for the annualscale comparison of predation potential was analogous to the second ANOVA performed on the seasonal-scale data. The years were blocks, and site and time of day were fixed factors. Site and time of day showed significant effects, with predation potential once again greater in St. Croix than in Jamaica, and greater during the day than at

\section{RESULTS}

\section{Predation potential on two scales}

The primary predators of ophiuroids in Caribbean back-reef habitats are wrasses (Labridae) during the day, and grunts (Haemulidae) and porcupinefish (Diodontidae) at night (Aronson 1992b). Predation potential, as measured by the mortality of Ophiothrix orstedii in the tethering experiments, showed similar within-site variation and between-site differences on both scales. On both the seasonal and annual scales, predation potential was highly variable at both sites in the daytime, although it tended to be higher in St. Croix (Fig. 1A, C). Nighttime predation potential was consistently higher in St. Croix on both scales (Fig. 1B, D). Bivariate plots of daytime against nighttime mortality showed clear separation of the sites, as well as generally greater daytime mortality than nighttime mortality (Fig. 2).

A randomized incomplete-block ANOVA of the seasonal-scale tethering data showed no significant night (Table 3, Fig, 2B). The site $\times$ time interaction was not significant, nor was there a significant block effect.

Table 1. ANOVA table for randomized incomplete-block analysis of seasonal-scale tethering data from Jamaica and St. Croix (arcsine-transformed). The 3 years over which seasonal data were collected are treated as the blocks. The effect of year is tested under the assumption of no block $\times$ factor interactions (see text)

\begin{tabular}{|c|c|c|c|c|c|}
\hline Source & $\begin{array}{l}\text { Sum of } \\
\text { squares }\end{array}$ & df & $\begin{array}{l}\text { Mean } \\
\text { square }\end{array}$ & $F$ & $\mathrm{p}$ \\
\hline Year (Block) & 0.071 .9 & 2 & 0.0359 & 0.6604 & 0.530 \\
\hline Site & 1.2523 & 1 & 1.2523 & 23.0088 & 0.0002 \\
\hline Season & 0.1253 & 2 & 0.0626 & 1.1508 & 0.341 \\
\hline Time of day & 0.3391 & 1 & 0.3391 & 6.2297 & 0.024 \\
\hline Site $\times$ Season & 0.0089 & 2 & 0.0045 & 0.0819 & 0.922 \\
\hline Site $\times$ Time & 0.0406 & 1 & 0.0406 & 0.7451 & 0.401 \\
\hline Season Time & 0.0432 & 2 & 0.0216 & 0.3968 & 0.679 \\
\hline Site $\times$ Season $\times$ Time & 0.0733 & 2 & 0.0366 & 0.6731 & 0.524 \\
\hline Error & 0.8709 & 16 & 0.0544 & & \\
\hline
\end{tabular}



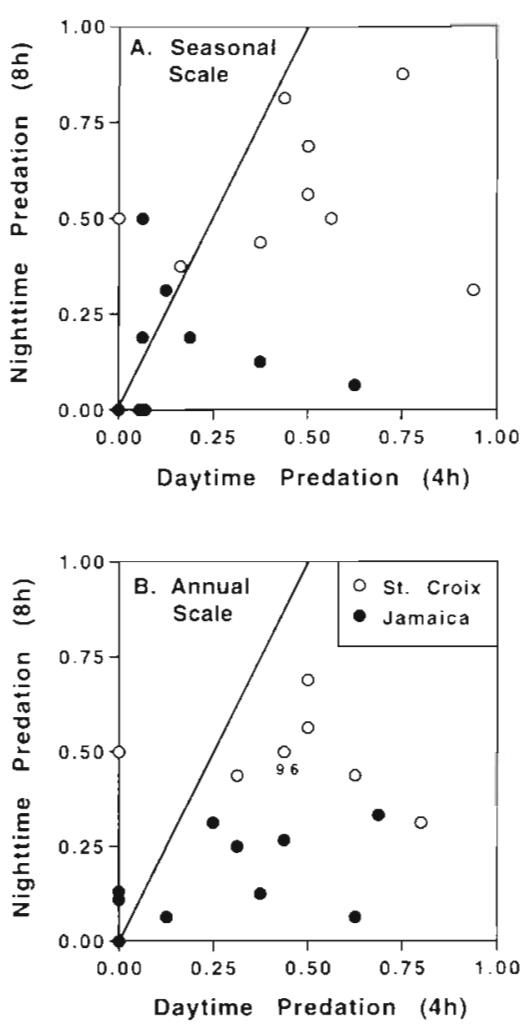

Fig. 2. Bivariate plots of proportional daytime versus proportional nighttime mortality of tethered Ophiothrix orstedii. Solid lines represent equal daytime and nighttime mortality. (A) Seasonal-scale data, collected during the period $1989-$ 1991. Spring data, omitted from statistical analysis, are included in the figure as available. (B) Annual-scale data, collected during the period 1986-1996. The 1996 St. Croix point (labeled '96') clusters with the other St. Croix points, despite hurricanes in 1995 and 1996

\section{Hurricane effects}

Aronson (1991, 1992b, 1993) found no short-term effects of Hurricane Gilbert in Jamaica (September 1988) or Hurricane Hugo in St. Croix (September 1989) on ophiuroid abundance or fish-ophiuroid trophic

Table 2. Randomized incomplete-block ANOVA of seasonalscale tethering data from Jamaica and St. Croix (arcsinetransformed). Each of the 3 seasons sampled in each year is treated as a block. The block effect is tested as in Table 1

\begin{tabular}{|lrrrrc}
\hline Source & $\begin{array}{c}\text { Sum of } \\
\text { squares }\end{array}$ & df & $\begin{array}{c}\text { Mean } \\
\text { square }\end{array}$ & $F$ & $\mathrm{p}$ \\
\hline Season (Block) & 0.4084 & 8 & 0.0510 & 1.1018 & 0.406 \\
Site & 1.4023 & 1 & 1.4023 & 30.2694 & $<0.0001$ \\
Time of day & 0.4049 & 1 & 0.4049 & 8.7404 & 0.008 \\
Site $\times$ Time & 0.0409 & 1 & 0.0409 & 0.8833 & 0.360 \\
Error & 0.8339 & 18 & 0.0463 & & \\
& & & & & \\
\hline
\end{tabular}

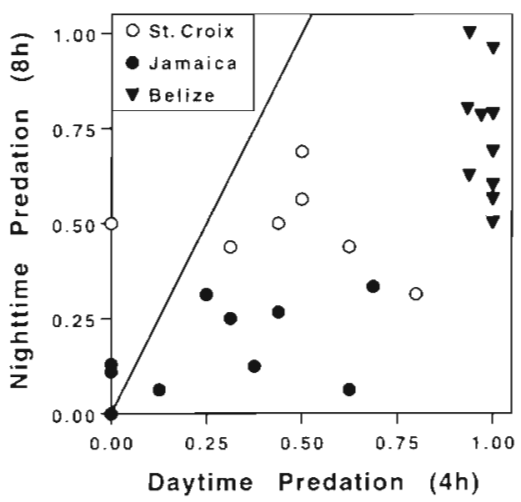

Fig. 3. Bivariate plot of annual-scale daytime versus nighttime mortality of tethered Ophiothrix orstedii in Jamaica, St. Croix, and Belize. Line of equal daytime and nighttime predation as in Fig. 2

interactions over the period 1987-1991. There was no evidence in the present study for a delayed, long-term response of predation potential to these hurricanes. Two additional hurricanes affected St. Croix between the August 1994 and July 1996 site-visits: Hurricane Marilyn in September 1995 and Hurricane Bertha in July 1996. The latter hurricane struck $1 \mathrm{wk}$ prior to the 1996 site-visit. The St. Croix site appeared physically unaffected by these 2 storms, and there were no alterations in predation potential (Fig. 2B) or fish abundance.

\section{Predation potential in Belize}

Daytime predation potential, measured on the annual scale, was higher in Belize than at the other 2 sites (Fig. 3). In fact, predation potential was saturating in the $4 \mathrm{~h}$ daytime experiments; all the Ophiothrix orstedii were consumed in 6 of the 10 experiments. Nighttime predation potential overlapped with the results from St. Croix but was always higher than in Jamaica.

Table 3. Randomized incomplete-block ANOVA of annualscale tethering data from Jamaica and St. Croix (arcsinetransformed). The sampling years are treated as blocks, and the block effect is tested as in Table 1

\begin{tabular}{|lcrrcc|}
\hline Source & $\begin{array}{c}\text { Sum of } \\
\text { squares }\end{array}$ & df & $\begin{array}{c}\text { Mean } \\
\text { square }\end{array}$ & $F$ & $\mathrm{p}$ \\
\hline Year (Block) & 1.0197 & 9 & 0.1133 & 2.1032 & 0.077 \\
Site & 0.3168 & 1 & 0.3168 & 5.8815 & 0.024 \\
Time of day & 0.3151 & 1 & 0.3151 & 5.8487 & 0.025 \\
Site X Time & 0.0010 & 1 & 0.0010 & 0.0188 & 0.892 \\
Error & 1.1313 & 21 & 0.0539 & & \\
& & & & & \\
\hline
\end{tabular}




\section{DISCUSSION}

The seasonal-scale analysis of predation potential in Jamaica and St. Croix detected significant effects of site and time of day. The same conclusions emerged from the annual-scale analysis. Thus, tethering experiments conducted on the seasonal scale over 3 yr predicted predation potential on the annual scale over a decade. The null hypotheses of scale independence outlined in the 'Introduction' could not be falsified at these scales.

Predation potential was higher in St. Croix than in Jamaica and, on the annual scale, higher in Belize than in St. Croix. Thus, as in the shorter-term study of Aronson (1992b), predation potential was higher where fishing pressure was lower. This association of predation potential and fishing pressure persisted for a decade.

Back-reef habitats are protected by their reef crests from almost all the energy of incoming storm waves (Roberts 1989). Nevertheless, hurricanes can cause significant changes in cryptofaunal abundance (Moran \& Reaka-Kudla 1991). Hurricane Gilbert in Jamaica and Hurricanes Hugo, Marilyn, and Bertha in St. Croix had no noticeable effect on predation potential in the back reef during the course of this study.

Almost nothing is known about the lifespans or generation times of Caribbean ophiuroid species (G. L. Hendler pers. comm.). Likewise, the turnover times of their predators - labrids, haemulids, and diodontidshave not been well studied (J. A. Bohnsack pers. comm.). It is not possible, therefore, to evaluate the 'stability' of predation potential by the criterion of Connell \& Sousa (1983), who required persistence through at least 1 complete turnover of the species assemblage. Sutherland (1990; see also Peterson 1984) objected to the turnover requirement as unnecessarily strict for judging whether a community or other ecological entity is resistant to perturbation. Sutherland (1990) argued that, since potential perturbations occur on multiple scales, persistence through those perturbations is of interest regardless of whether the community can be observed over the course of a complete turnover. The constancy of predation potential through hurricanes at both field sites is an indication that this trophic parameter is stable on these scales, at least by the persistence or resistance criteria

How widely these results can be applied, whether back-reef communities differ fundamentally from forereef communities in their response to disturbance, and how larval supply influences trophic dynamics on coral reefs are questions for future research. Much remains to be learmed about how scale influences our perception of stability (Pimm 1991). The same can be said for the influence of scale on ecological and evolutionary phenomena in general. It is always possible to find an upper or lower scale at which the usual patterns do not hold. The rare, high-amplitude events that provided the rubble under which the ophiuroids live are evidence for scale dependence on scales greater than those studied here. Nevertheless, the current penchant for scale-dependent explanations often obscures the value of scale-independent null models (Levinton 1988, Hoffman 1989, Williams 1992, Smith 1994). At the very least, these null models should be restored to their rightful position in the enterprise of hypothesistesting. They require fewer assumptions about emergent properties, and they should be adopted when they offer greater explanatory and predictive power over an ecologically relevant range of scales (cf. Wiens 1989).

Acknowledgements. This study was supported by the National Geographic Society, the Smithsonian Institution's Scholarly Studies Program, NOAA's National Undersea Research Program (NURP), Northeastern University's East/ West Program, the Smithsonian's Caribbean Coral Reef Ecosystems (CCRE) Program, and the Dauphin Island Sea Lab (DISL). Many colleagues, students, and friends assisted me in the field over the years. I am particularly grateful to Bill Cleveland, Bill Fitt, Jon Havenhand, Julia Miles, Rick Nemeth, Bill Precht, Dione Swanson, Chris Thomann, and Lisa Young for helping out at various times and places. Steven Miller (NURP), John Ogden and Betsy Gladfelter (West Indies Laboratory), John and Mary Bythell, Dave Carlon, Bob and Heddy Carpenter, John Ebersole, Dennis Hubbard, Jeff Miller, Karla Parsons, Peter Sale, and Nick Tolimieri provided logistical support in St. Croix, and Jeremy Woodley and Mike Halley facilitated my research at the Discovery Bay Marine Laboratory (DBML), Jamaica. Klaus Ruetzle? provided access to the Smithsonian's field station at Carrie Bow Cay, Belize. Editorial work by Ron Karlson, the comments of 3 anonymous reviewers, and discussions with Marty Buzas, Ron Etter, Jon Havenhand, Ken Heck, Lisa Kellogg, Thad Murdoch, Dave Pawson, and John Valentine improved the paper substantially. This is DISL Contribution No. 300, DBML Contribution No. 604, and CCRE Contribution No. 547

\section{LITERATURE CITED}

Allen TFH, Starr TB (1982) Hierarchy: perspectives for ecological complexity. University of Chicago Press, Chicago Appleton RD, Palmer AR (1988) Water-borne stimuli released by predatory crabs and damaged prey induce more predator-resistant shells in a marine gastropod. Proc Natl Acad Sci USA 85:4387-4391

Aronson RB (1987) Predation on fossil and Recent ophiuroids. Paleobiology 13:187-192

Aronson RB (1988) Palatability of tive Caribbean ophiuroids. Bull Mar Sci 43:93-97

Aronson RB (1989a) Brittlestar beds: low-predation anachronisms in the British Isles. Ecology 70:856-865

Aronson RB (1989b) A community-level test of the Mesozoic marine revolution theory. Paleobiology 15:20-25

Aronson RB (1991) Predation, physical disturbance, and sublethal arm damage in ophiuroids: a Jurassic-Recent comparison. Mar Ecol Prog Ser 74:91-97 
Aronson RB (1992a) Biology of a scale-independent predatorprey interaction. Mar Ecol Prog Ser 89:1-13

Aronson RB (1992b) The effects of geography and hurricane disturbance on a tropical predator-prey interaction. J Exp Mar Biol Ecol 162:15-33

Aronson RB (1993) Hurricane effects on backreef echinoderms of the Caribbean. Coral Reefs 12:139-142

Aronson RB (1994) Scale-independent biological interactions in the marine environment. Oceanogr Mar Biol Annu Rev $32: 435-460$

Aronson RB, Blake DB, Oji T (1997) Retrograde community structure in the late Eocene of Antarctica. Geology 25 903-906

Aronson RB, Harms CA (1985) Ophiuroids in a Bahamian saitwater lake: the ecology of a Paleozoic-like community Ecology 66:1472-1483

A.ronson RB, Heck KL Jr (1995) Tethering experiments and hypothesis testing in ecology. Mar Ecol Prog Ser 121 307-309

Aronson RB, Plotnick RE (in press) Scale-independent interpretations of macroevolutionary dynamics. In: Mckinney ML (ed) Biodiversity dynamirs: turnover of populations, taxa and communities. Columbia University Press, New York

Aronson RB, Sues HD (1987) The paleoecological significance of an anachronistic ophiuroid community. In: Kerfoot WC, Sih A (eds) Predation: direct and indirect impacts on aquatic communities. University Press of New England, Hanover, NH, p 355-366

Brown JH (1995) Macroecology. University of Chicago Press, Chicago

Chesson P. Huntley N (1989) Short-term instabilities and long-term community dynamics. Trends Ecol Evol 4: 293-298

Connell JH (1983) On the prevalence and relative importance of interspecific competition: evidence from field experiments. Am Nat 122:661-696

Connell JH, Sousa WP (1983) On the evidence needed to judge ecological stability or persistence. Am Nat 121 $789-824$

Csada RD, James PC, Espie RHM (1996) The 'file drawer problem' of non-significant results: does it apply to biological research? Oikos 76:591-593

Dayton PK, Tegner MJ (1984) The importance of scale in community ecology: a kelp forest example with terrestrial analogs. In: Price PW, Slobodchikoff CN, Gaud WS (eds) A new ecology: novel approaches to interactive systems. Wiley, New York, p 457-481

Dayton PK, Tegner MJ, Parnell PE, Edwards PB (1992) Temporal and spatial patterns of disturbance and recovery in a kelp forest community. Ecol Monogr 62:421-445

Doherty P, Fowler T (1994) An empirical test of recruitment limitation in a coral reef fish. Science 263:935-939

Gould SJ (1981) Palaeontology plus ecology as palaeobiology. In: May RM (ed) Theoretical ecology: principles and applications, 2nd edn. Sinauer, Sunderland, MA, p 295-317

Gould SJ (1985) The paradox of the first tier: an agenda for paleobiology. Paleobiology 11:2-12

Hendler G, Littman BS (1986) The ploys of sex: relationships among the mode of reproduction, body size and habitats of coral reef brittlestars. Coral Reefs 5:31-42

Hoffman A (1989) Arguments on evolution: a paleontologist's perspective. Oxford University Press, New York

Holme NA (1984) Fluctuations of Ophiothrix fragilis in the western English Channel. J Mar Biol Assoc UK 64: $351-378$

Hughes RN, Elner RW (1979) Tactics of a predator, Carcinus maenas, and morphological responses of the prey, Nucella Japillus. J Anim Ecol 48:65-78

Kissling DL, Taylor GT (1977) Habitat factors for reefdwelling ophiuroids in the Florida Keys. Proc 3rd Int Coral Reef Symp 1:225-231

Kitching JA, Lockwood J (1974) Observations on shell form and its ecological significance in thaisid gastropods of the genus Lepisella in New Zealand. Mar Biol 28:131-144

Levin S (1992) The problem of pattern and scale in ecology. Ecology 73:1943-1967

Levin SA, Grenfall B, Hastings A, Perelson AS (1997) Mathematical and computational challenges in population biology and ecosystems science. Science 275:334-343

Levinton J (1988) Genetics, palcontolugy, and macroevolution. Cambridge University Press, Cambridge

Lewis JB, Bray RD (1983) Community structure of ophiuroids (Echinodermata) from three different habitats on a coral reef in Barbados, West Indies. Mar Biol 73:171-176

Menge BA (1995) Indirect effects in marine rocky intertidal interaction webs: patterns and importance. Ecol Monogr $65: 21-74$

Menge BA, Olson AM (1990) Role of scale and environmental factors in regulation of community structure. Trends Ecol Evol 5:52-57

Meyer DL (1985) Evolutionary implications of predation on Recent comatulid crinoids from the Grect Barrier Reef. Paleobiology 11:154-164

Meyer DL, Macurda DB Jr (1977) Adaptive radiation of the comatulid crinoids. Paleobiology 28:629-642

Miller W III (ed) (1990) Paleocommunity temporal dynamics: the long-term development of multispecies assemblages. Paleontological Society Spec Pub 5, University of Tennessee, Knoxville

Moran DP, Reaka-Kudla ML (1991) Effects of disturbance: disruption and enhancement of coral reef cryptofaunal populations by hurricanes. Coral Reefs $9: 215=224$

Newman JA, Bergelson J, Grafen A (1997) Blocking factors and hypothesis tests in ecology: is your statistics text wrong? Ecology 78:1312-1320

Oji T (1985) Early Cretaceous Isocrinus from northwest Japan. Palaeontology 28:629-642

O'Neill RV, DeAngelis DL, Waide JB, Allen TFH (1986) A hierarchical concept of ecosystems. Princeton University Press, Princeton

Peters RH (1991) A critique for ecology. Cambridge University Press, Cambridge

Peterson CH (1984) Does a rigorous criterion for environmental identity preclude the existence of multiple stable points? Am Nat 124:127-133

Peterson CH, Black R (1994) An fxpermentalist's challenge when artifacts of intervention interact with treatments. Mar Ecol Prog Ser 111:289-297

Pimm SL (1991) The balance of nature? University of Chicago Press, Chicago

Roberts HH (1989) Physical processes as agents of sediment transport in carbonate systems: examples from St. Croix, U.S.V.I. In: Hubbard DK (ed) Terrestrial and marine geology of St. Croix, U.S. Virgin Islands. West Indies Laboratory Spec Pub 8, St. Croix, p 95-104

Schneider DC (1994) Quantitative ecology: spatial and temporal scaling. Academic Press, San Diego

Seeley RH (1986) Intense natural selection caused a rapid morphological transition in a living marine snail. Proc Natl Acad Sci USA 83:6897-6901

Sides EM (1987) An experimental study of the use of arm regeneration in estimating rates of sublethal injury in brittle-stars. J Exp Mar Biol Ecol 106:1-16 
Sides EM, Woodley JD (1985) Niche separation in three species of Ophiocoma (Echinodermata: Ophiuroidea) in Jamaica, West Indies. Bull Mar Sci 36:701-715

Sloan NA, Clark AM, Taylor JD (1979) The echinoderms of Aldabra and their habitats. Bull British Mus Nat Hist (Zool) 37:81-128

Smith AB (1994) Systematics and the fossil record: documenting evolutionary patterns. Blackwell, Oxford

Sokal RR, Rohlf FJ (1981) Biometry, 2nd edn. Freeman, San Francisco

Sutherland JP (1990) Perturbations, resistance, and alternative views of the existence of multiple stable points in nature. Am Nat 136:270-275

Thrush SF, Schneider DC, Legendre P, Whitlatch RB, Dayton PK, Hewitt JE, Hines AH, Cummings VJ, Lawrie SM, Grant J, Pridmore RD, Turner SJ, McArdle BH (1997) Scaling-up from experiments to complex ecological systems: where to next? J Exp Mar Biol Ecol 216:243-254

Underwood AJ, Chapman MG (1996) Scales of spatial patterns of distribution of intertidal invertebrates. Oecologia $107: 212-224$

Vermeij GJ (1977) The Mesozoic marine revolution: evidence from snails, predators and grazers. Paleobiology 3:245-258

Vermeij GJ (1978) Biogeography and adaptation: patterns of

Editorial responsibility: Ronald Karlson (Contributing Editor), Newark, Delaware, USA marine life. Harvard University Press, Cambridge, MA Vermeij GJ (1987) Evolution and escalation: an ecological history of life. Princeton University Press, Princeton

Wellington GM, Kuris AM (1983) Growth and shell variation in the tropical Eastern Pacific intertidal gastropod genus Purpura: ecological and evolutionary implications. Biol Bull 164:518-535

West K, Cohen A, Baron M (1991) Morphology and behavior of crabs and gastropods from Lake Tanganyika, Africa: implications for lacustrine predator-prey coevolution. Evolution 45:589-607

White PS, Pickett STA (1985) Natural disturbance and patch dynamics: an introduction. In: Pickett STA, White PS (eds) The ecology of natural disturbances and patch dynamics. Academic Press, Orlando, p 3-13

Wiens JA (1989) Spatial scaling in ecology. Funct Ecol 3: $385-397$

Williams GC (1992) Natural selection: domains, levels, and challenges. Oxford University Press, New York

Wu J, Loucks OL (1995) From balance of nature to hierarchical patch dynamics: a paradigm shift in ecology. $Q$ Rev Biol 70:439-466

Zar JH (1984) Biostatistical analysis, 2nd edn. Prentice Hall, Englewood Cliffs

Submitted: January 9, 1998; Accepted: July 16, 1998

Proofs received from author(s): September 21, 1998 